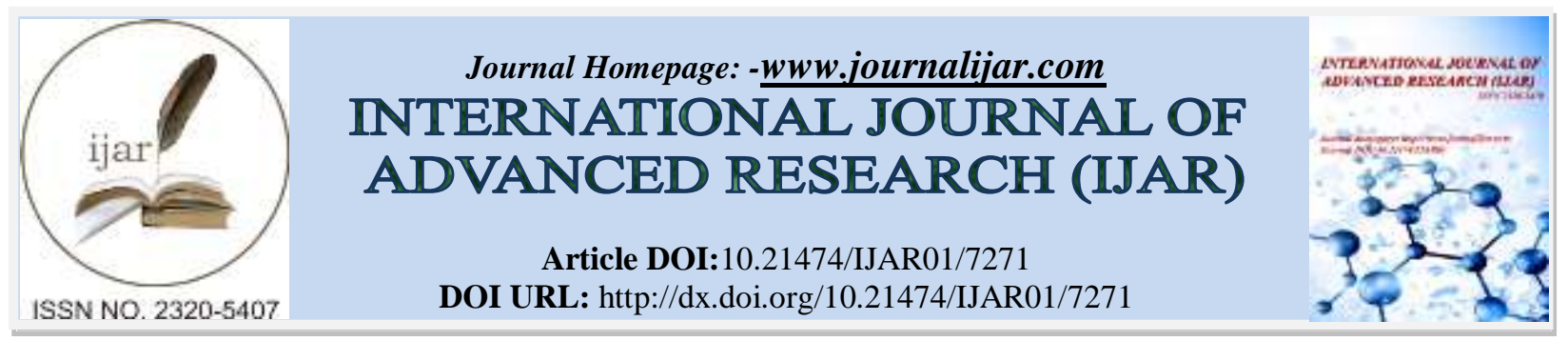

RESEARCH ARTICLE

\title{
IMPROVING MOTIVATION AND STUDENT LEARNING OUTCOME ON GEOMETRY TRANSFORMATIONSUBJECT WITH USING MODULES BASED ON GUIDED DISCOVERY.
}

\author{
R. Febriana, Y. Haryono and R. Yusri. \\ Mathematic Education Department STKIP PGRI Sumatera Barat, Padang, West Sumatera, Indonesia.
}

\section{Manuscript Info}

Manuscript History

Received: 12 April 2018

Final Accepted: 14 May 2018

Published: June 2018

Keywords:-

Learning motivation, learning result, module, guided discovery.

\begin{abstract}
Motivation and student learning outcomes depend on the learning strategy, learning media, and teaching materials used. Teaching materials used in the subject of Geometry transformation has not been able to increase motivation, interest and student learning outcomes. As a result, learning objectives and student learning outcomes are low. Therefore, it has developed teaching materials (module based on guided discovery). The purpose of this study was to determine the effect of the use of module based on guided discovery on student's motivation and learning outcomes in the subject of Geometry transformation. This research method is quasi experiment with research design one group pretest-posttest design. Sampling technique using is purposive sampling. Instruments in this study are questionnaires and test results learning. The result of the study showed that the students' learning motivation influenced $79 \%$ and $21 \%$ learning outcomes influenced by other factors. The effectiveness of student module and motivation have a significant effect on students' learning result in the course of Geometry of transformation. The module based on guided discovery causes students to be actively involved in the learning process and creatively find solutions to the problems they are given.
\end{abstract}

Copy Right, IJAR, 2018,. All rights reserved.

\section{Introduction:-}

Increased motivation and student learning outcomes depend on the learning strategy, learning media, and teaching materials used. Teaching materials is one part of teaching resources that can be interpreted something that contains learning messages, both specific and general nature that can be utilized for the benefit of learning (Mulyasa, 2006). Dick and Carey (2009) add that the instructional material contain the contents of written, mediated, or facilitated by an instructor that a student as the use of progress.

Teaching materials used in the subject of Geometry transformation has not been able to increase motivation, interest and student learning outcomes. As a result, learning objectives and student learning outcomes are low. Therefore, it has developed teaching materials (module based on guided discovery). Modul based on guided discovery is a learning model that focuses on learning in the systematic thinking process of search anddiscovery (Perwitasari and Djukri, 2018). The purpose of this study was to determine the effect of the use of module based on guided discovery student's motivation and learning outcomes in the subject of Geometry transformation. Hernandez et al. (2011) 
emphasized that guided discovery instruction could help learners learn various problem-solving strategies, transfer cognitive data to be useful, and know how to commence learning.

\section{Methods:-}

This research method is quasi experiment with research design one group pretest-posttest design. The research was conducted in mathematics education program, STKIP PGRI Sumatera Barat. The population in this study is all students of semester 2016/2017 who follow the course of Geometry Transformation. Sampling technique using purposive Sampling. Instruments in this study are questionnaires and test results learning. Data analysis technique used is the correlation coefficient person and multiple regression analysis. The prerequisite test conducted before performing regression analysis is the normality test, linearity test, multicollinearity test and heteroscedasticity test. The data are then analyzed using multiple regression analysis technique.

\section{Results and Discussion:-}

Based on the result of questionnaire of learning motivation toward result of study which have given to student show that sig value $<0,05$ means $\mathrm{H} 0$ is rejected. This means that motivation effect on student learning outcomes (Table $1)$.

Table 1:-Table ANOVA Regression Analysis Motivation Learning Against Student Learning Outcomes

\begin{tabular}{|c|l|l|c|c|c|c|}
\hline \multicolumn{2}{|c|}{ Model } & $\begin{array}{c}\text { Sum of } \\
\text { Squares }\end{array}$ & Df & Mean Square & F & Sig. \\
\hline \multirow{2}{*}{1} & Regression & 305.507 & 2 & 152.753 & 50.630 & $.000^{\mathrm{a}}$ \\
\cline { 2 - 7 } & Residual & 81.460 & 27 & 3.017 & & \\
\cline { 2 - 7 } & Total & 386.967 & 29 & & & \\
\hline
\end{tabular}

To know the effect of student's motivation on learning outcomes in the course of Geometry tarnsformasi, can be seen on Out put Model Summary as shown in Table 2 below.

Table 2:-Out put model summary model regression analysis of student motivation against student learning outcomes

\begin{tabular}{|c|c|c|c|c|c|}
\hline \multicolumn{2}{|c|}{ Model } & R & R Square & Adjusted R Square & Std. Error of the Estimate \\
\hline Dimension & 1 & $.889^{\mathrm{a}}$ & .789 & .774 & 1.7370 \\
\hline
\end{tabular}

Table 2 shows that students' learning motivation influences student's learning outcomes of 0.789 or $79 \%$ and $21 \%$ is influenced by other factors. The results of Alhadi and Saputra's research (2017) in Junior High School of Yogyakarta City found that the motivation to learn has a relationship with learning outcomes in the students of Junior High School of Yogyakarta City. The influence of learning motivation on learning outcomes is $21.5 \%$ while the rest is influenced by other variables. The motivation and the result of the student role as the students who learn and guidence to the students. Similarly, the results of the study by Sartawi et al (2012) found that the extent to which self-efficacy and motivation served as a predictor for mathematics achievement of fifth grade students in the United Arab Emirates (UAE) across gender and achievement levels. The regression equation can be seen in Out Put Coefficients as shown in Table 3.

Table 3:-Out put coefficients regression analysis effectiveness of module, questionnaire motivation and student learning outcomes.

\begin{tabular}{|l|l|r|r|r|r|r|}
\hline \multicolumn{2}{|c|}{ Model } & \multicolumn{2}{|c|}{ Unstandardized Coefficients } & \multicolumn{2}{c|}{$\begin{array}{c}\text { Standardized } \\
\text { Coefficients }\end{array}$} & \multirow{2}{*}{ Sig. } \\
\cline { 3 - 7 } \multicolumn{2}{|c|}{} & B & Std. Error & Beta & \\
\hline \multirow{2}{*}{1} & (Constant) & 41.164 & 7.447 & & 5.527 & .000 \\
\cline { 2 - 7 } & Motivasi & .642 & .378 & .362 & 1.698 & .101 \\
\cline { 2 - 7 } & Efektifitas & .805 & .315 & .546 & 2.557 & .017 \\
\hline
\end{tabular}

Table 3 above shows that the sig value. $<0.05$, this means that the effectiveness of student module and motivation significantly affect student's learning outcomes. The relationship of influence between the effectiveness of the module and the student's learning motivation on the learning result is expressed by regression equation $Y=41,164+$ $0,642 \mathrm{X} 1+0,805 \mathrm{X} 2$. Where $\mathrm{Y}$ is the result of student learning and $\mathrm{X}$ is the effectiveness of student learning module and motivation. Price 41.164 is a constant value indicating that if the student does not have the motivation then the student's learning result is worth 41,164 . While the price of 0.642 and 0.805 is a regression coefficient indicating 
that each increase in effectiveness score and student learning motivation of 1, it will be accompanied by an increase in student learning outcomes of 0.642 if using a module and equal to 0.805 if it has a high learning motivation. According Riduwan (2006) motivation is a force or strength that arises from within students to provide readiness for the established goal is achieved.

The use of module and learning motivation affect student's learning outcomes in the course of Geometry transformation. This is because the module besd on guided discovery students to be actively involved in the learning process and creatively find solutions to the problems. The results of Obiero, 2018 show that the relationship between achievement motivation and mathematic performance amongst female learners and in selected urban girls' secondary schools in Kenya indicate positive relationship between achievement motivation and mathematics performance in the area of study.

The module based on guided discovery used provide clear guidance and guide students to be directly involved in the learning process. Students interact and exchange ideas so that their insights and thinking power grow and develop. The results of Perwitasari and Djukri (2018) suggest that the developed thematic-integrated module based on a guided-discovery was effective to improve the student's critical thinking and scientific attitude. The use of module based on guided discovery can improve motivation and assist students in understanding learning materials. Response and interest of students in the learning process will help students in improving learning outcomes. The results of Yulastri et al (2017) suggest that an entrepreneurship module by using product-based learning approach in vocational education is effective to improve the quality of entrepreneurial learning process in vocational education. The use of guided discovery-based modules is closely related to student motivation and learning outcomes.

\section{Acknowledgments:-}

The research team would like to thank all those who have supported this research especially the DRPM DIKTI who has funded this research.

\section{References:-}

1. Alhadi, S and Saputra, WNE. 2017. The Relationship between Learning Motivation and Learning Outcome of Junior High School Students in Yogyakarta. Advances in Social Science, Education and Humanities Research (ASSEHR). 66:138-142.

2. Dick, W., Carey, L., \&Carey, J.O. (2010). The Systematic Design of Intruction. Fifth Education New York: Longman.

3. Hernandez, B., Montaner, T., Sese, F. J.\&Urquizu, P. (2011). The role of social motivations in elearning: How do they affect usage and success of ICT interactive tools? Computers in Human Behavior.27:2224-2232.

4. Mulyasa, E. 2006. Kurikulum yang Disempurnakan. Bandung: PT Remaja Rosdakarya.

5. Obiero, J. 2018. The Relationship between AchievementMotivation and Mathematic PerformanceAmongst Female Learners and in SelectedUrban Girls' Secondary Schools in Kenya. Global Journal of Social Sciences Studies. 4(1):23-29.

6. Perwitasari,N and Djukri, D. 2018. Developing thematic-integrated module basedon a guided-discovery was effective to improve the student's critical thinking and scientific attitude. Jurnal Prima Edukasia. 6(1): 44-55.

7. Sartawi, A, Alsawaie, ON, Dodeen, Tibi, H, N, Alghazo, IM. 2012.Predicting Mathematics Achievement by Motivation and Self-Efficacy Across Gender and Achievement Levels. Interdisciplinary Journal of Teaching and Learning. 2(2): 59-79.

8. Riduwan. (2010). Belajar Mudah Penelitian untuk Guru, Karyawan, dan Peneliti Pemula. Bandung: Alfabeta.

9. Yulastri, A, Hidayat et al.,. (2017). Developing an Entrepreneurship Module by Using Product-Based Learning Approach in Vocational. International Journal of Environmental \& Science Education. 12(5): 1097-1109. 